\title{
Teacher Candidates' Cyberloafing Behaviors in Terms of Different Variables ${ }^{1}$
}

\author{
Yusuf Tarlk Tatlı, (MA) \\ Cukurova University/ Turkey \\ Fatma Sadık, (Assoc. Prof.) \\ Cukurova University/ Turkey
}

Doi:10.19044/ejes.v8no3a81

URL:http://dx.doi.org/10.19044/ejes.v8no3a81

Submitted: 09 June 2021

Accepted: 26 July 2021

Published: 30 September 2021
Copyright 2021 Author(s)

Under Creative Commons BY-NC-ND

4.0 OPEN ACCES

\begin{abstract}
This is a descriptive study in the survey model conducted to examine teacher candidates' cyberloafing behaviors in terms of different variables. The study population consists of teacher candidates attending different departments of a state university in the academic year 2017-2018. To create the sample, students from all grade levels in randomly chosen fields of study from different departments of Education Faculty. Research data were collected using the "Scale of Cyberloafing Activities" and the "Personal Information Form". The data collection tools were delivered from a total of 918 teacher candidates who participated in the study voluntarily. Descriptive statistics, the Mann-Whitney U, and the Kruskal-Wallis tests were applied for data analysis. As a result of the study, it was detected that the teacher candidates' level of cyberloafing in the educational setting was "low," and that they usually accessed social networks and news sites. With regard to gender, it was observed that male teacher candidates, and with regard to departments that Science, Social and Turkish Education students, engaged more in cyberloafing. More than half of the participants defined their internet usage skills on an advanced and expert level, and it was detected that the level of cyberloafing increased as expertise increased. It was determined that the level of cyberloafing increased in conjunction with an increasing frequency of teacher candidates' usage of the internet on their mobile phones during the lesson and increasing grade levels.
\end{abstract}

Key Words: Cyberloafing, teacher candidates, mobile phone, internet usage.

\section{Introduction}

Nowadays, information and communication technologies are developing rapidly and technological devices as well as the internet have become important parts of people's lives. The rapid proliferation of information and communication technology tools, especially the integration of the internet and mobile devices into the daily life, provide people with great convenience in doing their daily work; e.g. visiting daily news sites to obtain information, using social media networks (Facebook, Twitter, Instagram, etc.) to obtain and share information, using mobile or web tools such as WhatsApp and Facebook Messenger to communicate, and doing many daily tasks such as banking transactions and shopping with technological tools. In addition to personal use, the internet is used extensively by employers and employees in the management of business

\footnotetext{
${ }^{1}$ This study is based on Yusuf Tarık Tatl1's master's thesis, which was completed under the supervision of Fatma SADIK.
} 
processes such as information sharing, human resources management, or purchasing as stated by Demir and Tan (2018). In modern educational settings, the Internet makes notable contributions to education providing students with opportunities to learn languages, access online journals, do research, and visit virtual libraries (Rayan et al., 2016). In other words, the internet, which helps students to obtain the information they need, also enables them to be active and take responsibility in accessing information. However, with the start of utilizing internet access of institutions for personal purposes, a new concept called "cyberloafing, cyberslacking" entered the literature in the 2000s.

The concept of cyberloafing, which was first used by Lim (2002), is generally defined as individuals' usage of the internet access provided by the institution for issues not related to their work or for personal purposes. Cyberloafing is also specified as inefficient time spent on the internet (Ugrin, Pearson \& Odom, 2008), using e-mail and the internet for purposes not related to their work (Blanchard \& Henle, 2008), and junk computing (Bock \& Ho, 2009). Cyberloafing includes different activities such as personal e-mail exchange, surfing the internet, online shopping, engaging with social networks such as Facebook or Twitter, blog pages, accessing news and sports sites, sending and receiving messages, and accessing entertainment as well as gaming sites, and new dimensions continue to be added due to continuous advancements in technology (Candan \& İnce, 2016). The undesirable effects of cyberloafing in the workplace are generally described as delaying the completion of work, reducing productivity, and disturbing the environment (Andreassen, Torsheim \& Pallesen, 2014; Koay, Soh \& Chew, 2017). Therefore, in recent years, the features of workplaces (environment, workload, employees) pushing employees in public and private workplaces to cyberloafing and the demographic characteristics of individuals (such as age and gender) and their psychological needs, habits, as well as computer and internet usage skills have widely been examined (Ahmad \& Omar, 2017; Andreassen et al., 2014; Candan \& İnce, 2016; Demir\& Tan, 2018; Holguin, 2016; Huma, Hussain, Thurasamy, \& Malik, 2017; Koay et al. 2017).

In educational settings, cyberloafing is generally defined as students' usage of information technologies for extracurricular purposes during lessons (Akbulut et al. 2016). Cyberloafing behaviors in schools have appeared with the introduction of information technologies and internet usage in educational institutions, and it has been detected that students use the internet for activities that are not related to the lesson especially in computer laboratories (Arabac1, 2017; Şenel et al. 2019). According to recent studies, students' usage of the internet during the lesson for personal purposes distracts them, reduces their interest in the lessons, causing them to deal with extracurricular work, therefore adversely affecting their learning performance. This behavior also affects the effectiveness of the teacher in the lesson and complicates classroom management (Heflin, Shewmaker, \& Nguyen, 2017; Lepp, Barkley \& Aryn (2015). Therefore, the number of studies on cyberloafing conducted in the educational field has been increasing (Alanoğlu\& Karatabak, 2021; Soh, Koay \& Lim, 2018; Hayıt \& Dönmez, 2016, Sarhangpour, Baezzat \& Akbari, 2018; Wu, Mei \& Ugrin, 2018). Reviewing related literature reveals that, so far, studies were generally carried out with students enrolled in departments where computer technologies are taught. However, nowadays, it is possible to connect to the internet anytime and anywhere with mobile phones (Baert et al. 2020). According to TURKSTAT (2018) reports, $98 \%$ of adults have a mobile phone and $77 \%$ use smartphones. The report also reveals that $62 \%$ of the population connect to the internet with their mobile phones. Therefore, it is possible to observe students' tendency to do cycberloafing with their mobile phones during classes without the need for a computer in the classroom setting (Çınar \& Cinisli, 2018; Hayıt \& Dönmez, 2016; Seçkin \& Kerse, 2017). 
Today, one of the important educational goals is to train qualified teachers Jiang, Lin \& Mariano, 2016). Students' tendency to cyberloafing during lessons may negatively affect not only their own performance but also the performance of others by diverting their attention resulting in a decrease of the effectiveness of the teaching process. This might be an issue in training qualified teachers as well. However, when the related literature was reviewed, it was observed that there is a limited number of research on teacher candidates or teacher candidates enrolled at education faculties (Arıkan \& Özgür, 2019; Doğusoy et al., 2020) and existing studies were mostly carried out with computer and instructional technology teacher candidates (Çınar \& Cinisli, 2018; Şenel et al., 2019; Varol \& Y1ldırım, 2018; Y1ldırım, 2016). For these reasons, it was necessary to conduct research examining teacher candidates' cyberloafing behavior by using their mobile phones during the lesson based on different variables to find answers to the following questions:

1. What are teacher candidates' habits of using the internet on their mobile phones (MP)?

2. What is the level of teacher candidates' cyberloafing behavior during the lesson?

3. Do teacher candidates' cyberloafing levels during the lesson show significant differences according to gender, age, department, grade level, and their habits of using the internet on their mobile phones?

\section{Method:}

\section{Research Design}

This is a descriptive study examining teacher candidates' cyberloafing behaviors in terms of different variables in the survey model. In descriptive research, the reality is objectively observed, measured, and analyzed. The important thing is to observe and determine the reality appropriately.

\section{Population and Sample}

The study population consists of teacher candidates enrolled at different departments of an education faculty at a state university, namely Primary Education, Mathematics and Science, Turkish and Social Sciences, Fine Arts Education and Educational Sciences during the academic year 2017-2018. In order to form the sample of the population, students were randomly chosen from all class levels of single program departments or from randomly chosen class levels of multiple program departments. The questionnaires were delivered to the participants during their classes by the department instructors, and participation was voluntary. A total of 918 teacher candidates participated in the study. Demographic information of the participants of the study is presented in Table 1.

\begin{tabular}{llll}
\hline Variable & Groups & $\mathrm{f}$ & $\%$ \\
\hline \multirow{2}{*}{ Gender } & Male & 268 & 29.2 \\
& Female & 650 & 70.8 \\
& Total & 918 & 100.0 \\
\hline \multirow{3}{*}{ Age } & $18-20$ years & 394 & 42.9 \\
& $21-23$ years & 446 & 48.6 \\
& 24-27 years & 78 & 8.5 \\
\multirow{5}{*}{ Department } & Total & 918 & 100.0 \\
& Primary School Education & 112 & 12.2 \\
& Preschool Education & 170 & 18.5 \\
& Science Education & 113 & 12.3 \\
& Social Sciences Education & 135 & 14.7
\end{tabular}




\begin{tabular}{llll}
\hline & Turkish Education & 136 & 14.8 \\
& Art-work Education & 79 & 8.6 \\
& Guidance and Psychological & 173 & 18.8 \\
& Counseling & 918 & 100.0 \\
\hline & Total & 231 & 25.2 \\
& $1^{\text {st }}$ grade & 230 & 25.1 \\
Grade level & $2^{\text {nd }}$ grade & 284 & 30.9 \\
& $3^{\text {rd }}$ grade & 173 & 18.8 \\
& $4^{\text {th }}$ grade & 918 & 100.0 \\
\hline & Total & & \\
\hline
\end{tabular}

Table 1.

\section{Teacher Candidates' Demographic Information}

As seen in Table 1, more than two thirds of the participants are female. Approximately half of the participants (48.6\%) are aged 21-23, followed by the 18-20 age group with $42.9 \%$ and the 24-27 age group with $8.5 \%$. There are more participant students from Guidance and Psychological Counseling (\%18.6) and Preschool Education (\%18.5) departments compared to other departments and the lowest number of participants is 79 from Art-work Education (\%8.6). Of the participants, more than half are younger students (25.2\% first-grade and $25.1 \%$ second-grade) while $30.9 \%$ are enrolled at third-grade and $18.8 \%$ are fourth-grade students.

\section{Data Collection Tools}

The Scale of Cyberloafing Activities (SCA); developed by Blanchard \& Henle (2008), adapted into Turkish by Kalaycı (2010) and updated by Yaşar (2013), and the Personal Information Form developed by the researchers were used to collect the data.

The Scale of Cyberloafing Activities. Consists of four subscales including Personal Business (9 items), Search (4 items), Socialization (6 items) and News Follow-up (4 items), in total 23 items. As a result of a confirmatory factor analysis performed by Yaşar (2013), the fit indices between the four-factor model and the data were as follows: GFI $=0.92$; CFI $=0.92$; $\mathrm{NNFI}=0.90 ; \mathrm{RMSEA}=0.08$. The item load value of an item in the socialization subscale is .30 , while the item load values of all items in the other subscales vary between .41-.88. The scale's Cronbach's alpha reliability coefficients are .94 in the "Personal business" subscale, .77 in the "Search" subscale, .84 in the "Socialization" subscale, and .76 in the "News follow-up" subscale. A 5-point Likert spectrum (never, rarely, occasionally, usually, always) was used for the Rating. The scale includes statements such as "I visit social networks (Facebook, Twitter, etc.), I pursue interesting topics in search engines." The scale's Cronbach's alpha reliability, recalculated in line with the data obtained with this study, is .84 in the "Personal business" subscale, .84 in the "Search" subscale, .80 in the "Socialization" subscale, and .85 in the "News follow-up" subscale.

The Personal Information Form. It was designed to obtain information about teacher candidates with a total of 13 questions determining the demographic information of the students (gender, age, department, grade level) and their general mobile phone usage habits.

\section{Data Collection}

The research data was collected during the fall semester of the Academic Year 2017-2018. The data collection process was performed in a way that would not disrupt the lectures. The students were asked to respond voluntarily in approximately 20 minutes. 


\section{Data Analysis}

First of all, the obtained results from the SCA and the arithmetic mean as well as standard deviation of these scores were calculated to determine the cyberloafing behavior levels of teacher candidates. The results obtained were interpreted by evaluating them according to intervals of 1.00-1.80 as "Never", 1.81-2.60 as "Rarely", 2.61-3.40 as "Sometimes", 3.41-4.20 as "Usually", and 4.21-5.00 as "Always". Then, a Kolmogorov-Smirnov test was performed on the scale scores, and it was examined whether their distribution met the assumption of normality or not. Table 2 presents the normality test analysis results of the data obtained from the SCA.

\begin{tabular}{|c|c|c|c|c|c|c|}
\hline & \multicolumn{3}{|c|}{ Kolmogorov-Smirnov } & \multicolumn{3}{|c|}{ Shapiro-Wilk } \\
\hline & Statistic & Df & Sig. & Statistic & df & Sig. \\
\hline Personal business & .120 & 918 & .000 & .920 & 918 & .000 \\
\hline Search & .076 & 918 & .000 & .960 & 918 & .000 \\
\hline Socialization & .048 & 918 & .000 & .989 & 918 & .000 \\
\hline News follow-up & .070 & 918 & .000 & .964 & 918 & .000 \\
\hline Scale total score & .040 & 918 & .001 & .985 & 918 & .000 \\
\hline
\end{tabular}

Table 2.

Normality Test Analysis for the SCA scores

As seen in Table 2, the significance levels of the Kolmogorov-Smirnov and Shapiro-Wilk tests are less than .05. Therefore, non-parametric tests instead of parametric tests were used for comparing the scale scores of the participants, a Mann-Whitney $U$ test was performed for paired comparisons, and a Kruskal-Wallis test was conducted for multiple comparisons (Büyüköztürk, 2020). To see in favor of which groups the difference was in cases when there were significant differences as a result of the Kruskal-Wallis test, the Mann-Whitney U test was repeated on the paired comparisons of the groups, and the level of significance was accepted as .05.

\section{Findings:}

\section{Teacher candidates' Behavior of Using the Internet on a Mobile Phone (MP)}

Descriptive statistics on the internet usage behavior on MP of the teacher candidates participating in the study are presented in Table 3.

\begin{tabular}{llll}
\hline & Groups & $\mathrm{f}$ & $\%$ \\
\hline \multirow{3}{*}{$\begin{array}{l}\text { The duration of internet service } \\
\text { usage on MP }\end{array}$} & 1-4 years & 430 & 46.8 \\
& 5-9 years & 444 & 48.4 \\
& $10-13$ years & 44 & 4.8 \\
& Total & 918 & 100.0 \\
\hline \multirow{3}{*}{$\begin{array}{l}\text { Data connection time } \\
\text { internet on MP }\end{array}$} & Less than 1 hour & 62 & 6.8 \\
& & 326 & 35.5 \\
& 2-3 hours & 266 & 29.0 \\
& 4-5 hours & 264 & 28.8 \\
Internet usage skills on MP & More than 5 hours & 918 & 100.0 \\
\hline & Total & 425 & 46.3 \\
& Medium & 368 & 40.1 \\
& Advanced & 125 & 13.6 \\
& Expert & 918 & 100.0 \\
\hline & Total & 139 & 15.1
\end{tabular}




\begin{tabular}{|c|c|c|c|}
\hline \multirow{5}{*}{$\begin{array}{l}\text { The frequency of using the } \\
\text { internet on MP during the lesson }\end{array}$} & 1-2 times & 542 & 59.0 \\
\hline & 3-4 times & 134 & 14.6 \\
\hline & 5-6 times & 32 & 3.5 \\
\hline & At each opportunity & 71 & 7.7 \\
\hline & Total & 918 & 100.0 \\
\hline \multirow{6}{*}{$\begin{array}{l}\text { The time spent on the internet } \\
\text { (without interruption) using MP } \\
\text { during the lesson }\end{array}$} & Less than 1 minute & 359 & 39.1 \\
\hline & 2-3 minutes & 299 & 32.6 \\
\hline & 3-4 minutes & 136 & 14.8 \\
\hline & 5-6 minutes & 55 & 6.0 \\
\hline & More than 6 minutes & 69 & 7.5 \\
\hline & Total & 918 & 100.0 \\
\hline \multirow{6}{*}{$\begin{array}{l}\text { Perception of the appropriateness } \\
\text { of using the internet on MP } \\
\text { behavior during the lesson }\end{array}$} & $\begin{array}{l}\text { Definitely } \\
\text { inappropriate }\end{array}$ & 307 & 33.4 \\
\hline & Inappropriate & 402 & 43.8 \\
\hline & Undecided & 139 & 15.1 \\
\hline & Appropriate & 47 & 5.1 \\
\hline & Definitely appropriate & 23 & 2.5 \\
\hline & Total & 918 & 100.0 \\
\hline
\end{tabular}

Table 3.

\section{Descriptive Statistics on Teacher Candidates' Internet Usage Behavior on MP}

As seen in Table 3,48.4\% of the teacher candidates have been using internet service on MP for 5-9 years. While $35.5 \%$ of the participants stated the daily internet access time from MP as 2-3 hours, $29.0 \%$ stated that they used the internet for $4-5$ hours, and $28.8 \%$ for more than five hours a day. $46.3 \%$ of the participants described their internet usage skills on MP as "medium," $40.1 \%$ as "advanced," and $13.6 \%$ as "expert." $59.0 \%$ of the participants stated that they use the internet on MP during the lesson 1-2 times, 14.6\% 3-4 times, and the percentage of those who stated that they did not use the internet on their mobile phones at all during the lesson was $15.1 \%$. While $39.1 \%$ of the students defined the time spent on the internet using MP during the lesson as less than 1 minute, $32.6 \%$ stated that it took 2-3 minutes. When Table 3 is examined, it is observed that more than three quarter of the teacher candidates do not find it right to use the internet on MP during the lesson.

\section{Teacher candidates' Cyberloafing Levels}

Table 4 demonstrates the descriptive statistics of the participants' scores from the SCA.

\begin{tabular}{lll}
\hline & $\overline{\mathrm{X}}$ & $\mathrm{Sd}$ \\
\hline Personal business & 1.87 & .74 \\
Search & 2.51 & 1.02 \\
Socialization & 2.73 & .86 \\
News follow-up & 2.73 & 1.08 \\
Scale total score & 2.36 & .76 \\
\hline
\end{tabular}

Table 4.

\section{Descriptive Statistics of The SCA Scores $(N=918)$}

Upon examining Table 4, it is observed that teacher candidates obtained the highest score in the scale's "Socialization" ( $\overline{\mathrm{x}}=2.73)$ and "News follow-up" $(\overline{\mathrm{x}}=2.73)$ subscales, which was followed by the "Search" ( $\overline{\mathrm{x}}=2.51)$ subscale. Teacher candidates received the lowest score in the "Personal business" subscale $(\overline{\mathrm{x}}=1.87)$, and the arithmetic mean of the scale total score was 2.36 . 
This indicates that cyberloafing behaviors are mostly in the form of socializing and following the news.

\section{Investigation of Teacher candidates' Cyberloafing Levels According to Different Variables}

Table 5 presents the results of the Mann-Whitney U test of the participants' SCA scores according to gender.

\begin{tabular}{lllllll}
\hline & Group & $\mathrm{N}$ & $\begin{array}{l}\text { Mean } \\
\text { Rank }\end{array}$ & Rank Sum & $\mathrm{U}$ & $\mathrm{P}$ \\
\hline Personal & Male & 268 & 540.57 & 144872.50 & 65373.500 & $.000^{*}$ \\
business & Female & 650 & 426.07 & 276948.50 & & \\
Search & Male & 268 & 549.67 & 147312.00 & 62934.000 & $.000^{*}$ \\
& Female & 650 & 422.32 & 274509.00 & & \\
Socialization & Male & 268 & 531.87 & 142540.50 & 67705.500 & $.000^{*}$ \\
& Female & 650 & 429.66 & 279280.50 & & \\
News follow- & Male & 268 & 562.21 & 150672.50 & 57056.500 & $.000^{*}$ \\
up & Female & 650 & 417.15 & 271148.50 & & \\
Scale & Male & 268 & 562.21 & 150672.50 & 59573.500 & $.000^{*}$ \\
& & & & & & \\
\hline
\end{tabular}

Table 5.

The Mann-Whitney U Test Results according to Gender

When Table 5 is examined, it is observed that the mean scores of male teacher candidates in all subscales as well as overall are statistically higher than the mean scores of female teacher candidates $(\mathrm{p}<.05)$. The Kruskal-Wallis test results of the participants' SCA scores according to age are given in Table 6.

\begin{tabular}{|c|c|c|c|c|c|c|c|c|}
\hline & Group & & $\mathrm{N}$ & $\begin{array}{l}\text { Mean } \\
\text { Rank }\end{array}$ & $\chi^{2}$ & $\mathrm{Sd}$ & $\mathrm{p}$ & $\begin{array}{l}\text { Sign. } \\
\text { difference }\end{array}$ \\
\hline \multirow{4}{*}{$\begin{array}{l}\text { Personal } \\
\text { Business }\end{array}$} & $18-20$ & years & 304 & 12163 & \multirow[t]{4}{*}{16.474} & \multirow[t]{4}{*}{2} & \multirow[t]{4}{*}{$.000 *$} & \multirow[t]{4}{*}{$\mathrm{A}<\mathrm{B}, \mathrm{C}$} \\
\hline & (A) & & 594 & 421.05 & & & & \\
\hline & $\begin{array}{l}21-23 \\
\text { (B) }\end{array}$ & years & 446 & 495.34 & & & & \\
\hline & $\begin{array}{l}24-27 \\
\text { (C) }\end{array}$ & years & 78 & 445.84 & & & & \\
\hline \multirow[t]{3}{*}{ Search } & $\begin{array}{l}18-20 \\
\text { (A) }\end{array}$ & years & 394 & 432.94 & \multirow[t]{3}{*}{7.865} & \multirow[t]{3}{*}{2} & \multirow[t]{3}{*}{$.020 *$} & \multirow[t]{3}{*}{$A<B$} \\
\hline & $\begin{array}{l}21-23 \\
\text { (B) }\end{array}$ & years & 446 & 484.03 & & & & \\
\hline & $\begin{array}{l}24-27 \\
\text { (C) }\end{array}$ & years & 78 & 453.40 & & & & \\
\hline \multirow[t]{3}{*}{ Socialization } & $\begin{array}{l}18-20 \\
\text { (A) }\end{array}$ & years & 394 & 442.73 & \multirow[t]{3}{*}{9.969} & \multirow[t]{3}{*}{2} & \multirow[t]{3}{*}{$.007 *$} & \multirow[t]{3}{*}{$\mathrm{A}, \mathrm{C}<\mathrm{B}$} \\
\hline & $\begin{array}{l}21-23 \\
\text { (B) }\end{array}$ & years & 446 & 485.08 & & & & \\
\hline & $\begin{array}{l}24-27 \\
\text { (C) }\end{array}$ & years & 78 & 397.92 & & & & \\
\hline
\end{tabular}




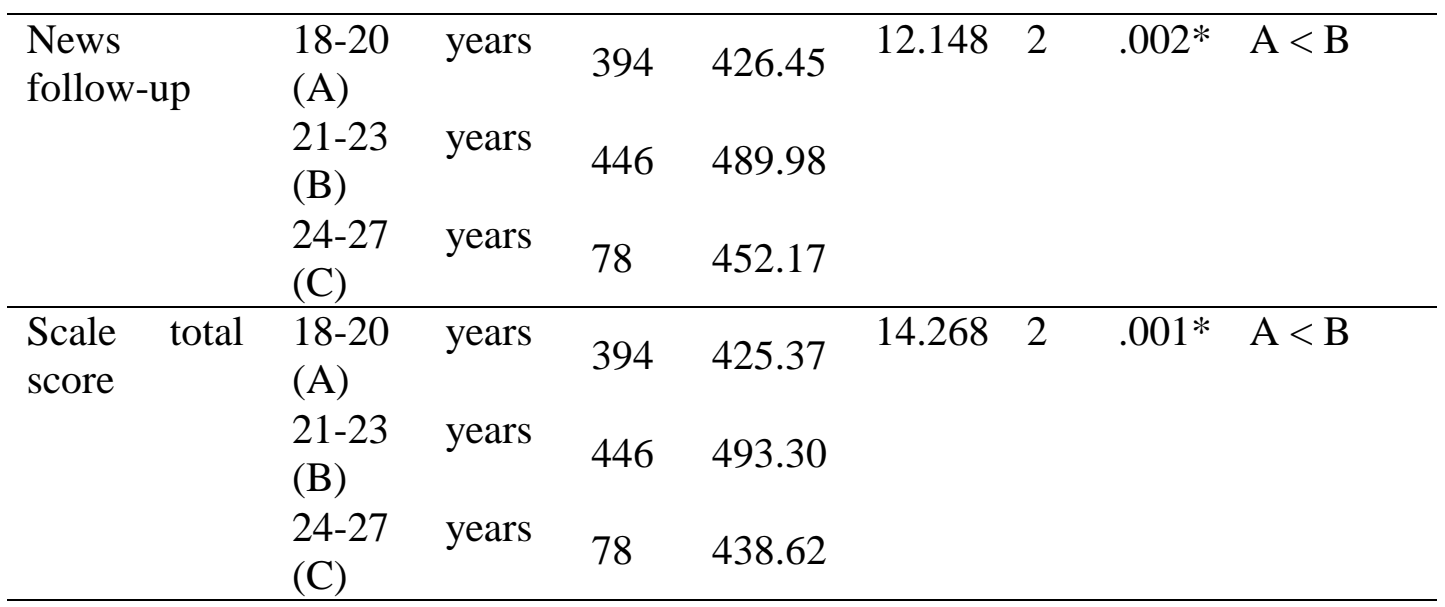

Table 6.

Kruskal-Wallis Test Results According to Age

As seen in Table 6, the mean scores of the teacher candidates in the 18-20 age range were significantly lower compared to the others $(\mathrm{p}<.05)$. Table 7 shows the Kruskal-Wallis test results for the SCA scores of the participants according to their departments.

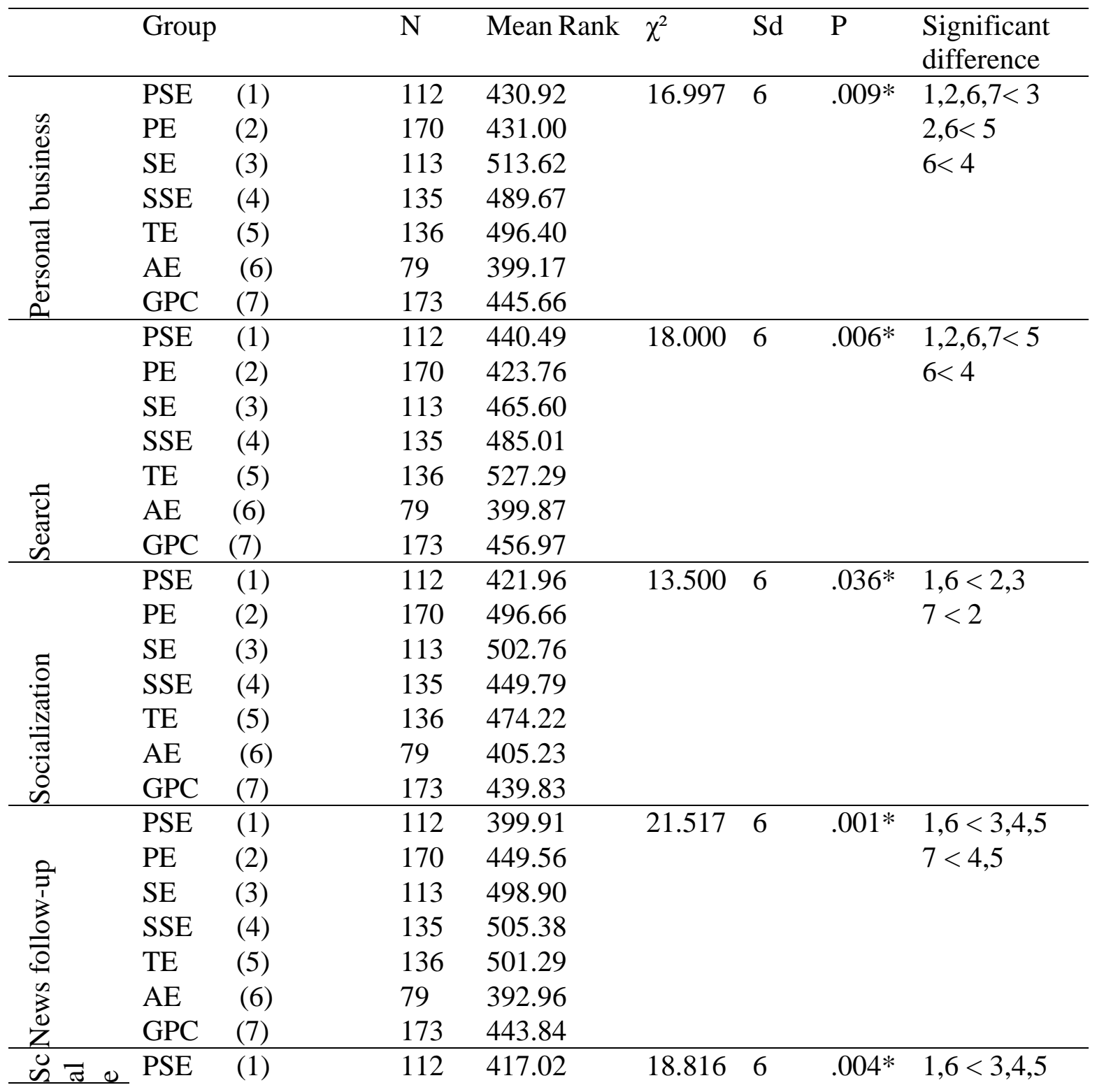




$\begin{array}{lllll}\text { PE } & (2) & 170 & 445.78 & 2,7<5 \\ \text { SE } & (3) & 113 & 506.35 & \\ \text { SSE } & (4) & 135 & 486.81 & \\ \text { TE } & (5) & 136 & 505.85 \\ \text { AE } & (6) & 79 & 387.34 \\ \text { GPC } & (7) & 173 & 445.09 & \text { Table } 7 .\end{array}$

Kruskal-Wallis Test Results According to Departments

$\mathrm{PSE}=$ Primary School Education, $\mathrm{PE}=$ Preschool Education, $\mathrm{SE}=$ Science Education, $\mathrm{SSE}=$ Social Sciences Education, TE $=$ Turkish Education, AE $=$ Art-work Education, GPC $=$ Guidance and Psychological Counseling Department

Table 7 shows that the department attended creates a significant difference in the participants' cyberloafing levels. According to the results of the Kruskal-Wallis test conducted on the binary combinations of the groups, the mean scores of SE, SSE, and TE students in the "Personal business," "News follow-up" subscales and overall of the scale and the mean scores of TE, SSE students in the "Search" subscale and the mean scores of PE and SE students in the "Socialization" subscale were statistically significantly higher $(\mathrm{p}<.05)$. Table 8 presents the Kruskal-Wallis test results of the participants' SCA scores according to grade levels.

\begin{tabular}{|c|c|c|c|c|c|c|c|}
\hline & Group & $\mathrm{N}$ & $\begin{array}{l}\text { Mean } \\
\text { Rank }\end{array}$ & $\chi^{2}$ & $\mathrm{Sd}$ & $\mathrm{P}$ & $\begin{array}{l}\text { Significant } \\
\text { difference }\end{array}$ \\
\hline \multirow[t]{4}{*}{$\begin{array}{l}\text { Personal } \\
\text { business }\end{array}$} & $\begin{array}{l}1^{\text {st }} \\
\text { grade }\end{array}$ & 231 & 394.98 & \multirow[t]{4}{*}{27.332} & \multirow[t]{4}{*}{3} & \multirow[t]{4}{*}{$.000 *$} & $1<2,3,4$ \\
\hline & $\begin{array}{l}2^{\text {nd }} \\
\text { grade }\end{array}$ & 230 & 495.27 & & & & $2<3$ \\
\hline & $\begin{array}{l}3^{\text {rd }} \\
\text { grade }\end{array}$ & 284 & 446.81 & & & & $3<4$ \\
\hline & $\begin{array}{l}4^{\text {th }} \\
\text { grade }\end{array}$ & 173 & 518.92 & & & & \\
\hline \multirow[t]{4}{*}{ Search } & $\begin{array}{l}1^{\text {st }} \\
\text { grade }\end{array}$ & 231 & 412.35 & \multirow[t]{4}{*}{12.979} & \multirow[t]{4}{*}{3} & \multirow[t]{4}{*}{$.005 *$} & \multirow[t]{4}{*}{$1<2,4$} \\
\hline & $\begin{array}{l}2^{\text {nd }} \\
\text { grade }\end{array}$ & 230 & 483.08 & & & & \\
\hline & $\begin{array}{l}3^{\text {rd }} \\
\text { grade }\end{array}$ & 284 & 455.17 & & & & \\
\hline & $\begin{array}{l}4^{\text {th }} \\
\text { grade }\end{array}$ & 173 & 498.22 & & & & \\
\hline \multirow[t]{4}{*}{ Socialization } & $\begin{array}{l}1^{\text {st }} \\
\text { grade }\end{array}$ & 231 & 420.54 & \multirow[t]{4}{*}{8.374} & \multirow[t]{4}{*}{3} & \multirow[t]{4}{*}{$.039 *$} & \multirow[t]{4}{*}{$1<2,4$} \\
\hline & $\begin{array}{l}2^{\text {nd }} \\
\text { grade }\end{array}$ & 230 & 483.92 & & & & \\
\hline & $\begin{array}{l}3^{\text {rd }} \\
\text { grade }\end{array}$ & 284 & 456.98 & & & & \\
\hline & $\begin{array}{l}4^{\text {th }} \\
\text { grade }\end{array}$ & 173 & 483.19 & & & & \\
\hline \multirow[t]{2}{*}{$\begin{array}{l}\text { News follow- } \\
\text { up }\end{array}$} & $\begin{array}{l}1^{\text {st }} \\
\text { grade }\end{array}$ & 231 & 415.43 & \multirow[t]{2}{*}{16.246} & \multirow[t]{2}{*}{3} & \multirow[t]{2}{*}{$.001 *$} & $1<2,4$ \\
\hline & $\begin{array}{l}2^{\text {nd }} \\
\text { grade }\end{array}$ & 230 & 480.07 & & & & $3<4$ \\
\hline
\end{tabular}




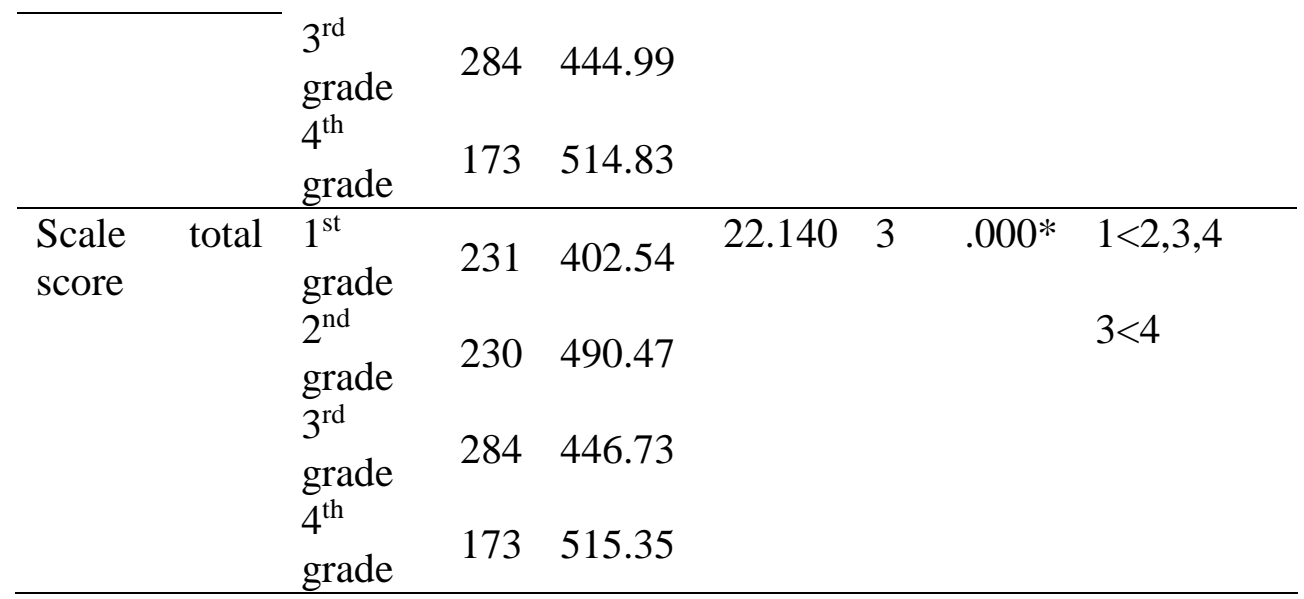

Table 8.

Kruskal-Wallis Test Results According to Grade Levels

According to the Kruskal-Wallis results in Table 8, as the grade levels increase, the mean scores of students in the "Personal business" subscale also increase statistically significant $(\mathrm{p}<.05)$. The significant difference observed in the "Search" and "Socialization" subscales is in favor of $2^{\text {nd }}$ and $4^{\text {th }}$ grade students among $1^{\text {st }}, 2^{\text {nd }}$ and $4^{\text {th }}$ grade students $(\mathrm{p}<.05)$. The significant differences observed in the "News follow-up" subscale were in favor of $2^{\text {nd }}$ and $4^{\text {th }}$ grade students among $1^{\text {st }}$, $2^{\text {nd }}$, and $4^{\text {th }}$ grade students and in favor of $4^{\text {th }}$ grade students among $3^{\text {rd }}$ and $4^{\text {th }}$ grade students $(\mathrm{p}$ <.05). When Table 8 is examined in terms of the total score of the scale, it is observed that the mean scores increase significantly toward the upper grades $(\mathrm{p}<.05)$. In Table 9 , the Kruskal-Wallis test results of the teacher candidates' SCA scores are given according to the duration of using internet service on MP.

\begin{tabular}{|c|c|c|c|c|c|c|}
\hline & Group & $\mathrm{N}$ & $\begin{array}{l}\text { Mean } \\
\text { Rank }\end{array}$ & $\chi^{2}$ & $\mathrm{Sd}$ & $\mathrm{P}$ \\
\hline \multirow{3}{*}{$\begin{array}{l}\text { Personal } \\
\text { business }\end{array}$} & $1-4$ years & 430 & 455.27 & \multirow[t]{3}{*}{2.675} & \multirow[t]{3}{*}{2} & \multirow[t]{3}{*}{.262} \\
\hline & $5-9$ years & 444 & 457.31 & & & \\
\hline & $\begin{array}{l}10-13 \\
\text { years }\end{array}$ & 44 & 522.99 & & & \\
\hline \multirow[t]{3}{*}{ Search } & 1-4 years & 430 & 460.83 & \multirow[t]{3}{*}{2.153} & \multirow[t]{3}{*}{2} & \multirow[t]{3}{*}{.341} \\
\hline & \multirow{2}{*}{$\begin{array}{l}5-9 \text { years } \\
10-13 \\
\text { years }\end{array}$} & 444 & 452.83 & & & \\
\hline & & 44 & 513.81 & & & \\
\hline \multirow[t]{3}{*}{ Socialization } & $1-4$ years & 430 & 450.07 & \multirow[t]{3}{*}{5.437} & \multirow[t]{3}{*}{2} & \multirow[t]{3}{*}{.066} \\
\hline & \multirow{2}{*}{$\begin{array}{l}5-9 \text { years } \\
10-13 \\
\text { years }\end{array}$} & 444 & 459.89 & & & \\
\hline & & 44 & 547.74 & & & \\
\hline \multirow{3}{*}{$\begin{array}{ll}\text { News follow- } \\
\text { up }\end{array}$} & $1-4$ years & 430 & 474.51 & \multirow[t]{3}{*}{5.119} & \multirow[t]{3}{*}{2} & \multirow[t]{3}{*}{.077} \\
\hline & 5-9 years & 444 & 440.31 & & & \\
\hline & $\begin{array}{l}10-13 \\
\text { years }\end{array}$ & 44 & 506.53 & & & \\
\hline \multirow{3}{*}{$\begin{array}{l}\text { Scale } \\
\text { score }\end{array}$} & $1-4$ years & 430 & 458.12 & \multirow[t]{3}{*}{4.623} & \multirow[t]{3}{*}{2} & \multirow[t]{3}{*}{.099} \\
\hline & 5-9 years & 444 & 452.61 & & & \\
\hline & $\begin{array}{l}10-13 \\
\text { years }\end{array}$ & 44 & 542.49 & & & \\
\hline
\end{tabular}

Table 9. 
As observed in Table 9, the duration of internet service usage on MP did not create statistically significant differences in the cyberloafing levels of teacher candidates $(\mathrm{p}>.05)$. The Kruskal-Wallis test results of the participants' SCA scores according to the daily connection time to the internet with MP are shown in Table 10.

\begin{tabular}{|c|c|c|c|c|c|c|c|}
\hline & Group & $\mathrm{N}$ & $\begin{array}{l}\text { Mean } \\
\text { Rank }\end{array}$ & $\chi^{2}$ & $\mathrm{Sd}$ & $\mathrm{p}$ & $\begin{array}{l}\text { Sign. } \\
\text { difference }\end{array}$ \\
\hline \multirow[t]{4}{*}{$\begin{array}{l}\text { Personal } \\
\text { business }\end{array}$} & $\begin{array}{l}\text { Less than } 1 \text { hour } \\
\text { (A) }\end{array}$ & 62 & 420.90 & \multirow[t]{4}{*}{6.227} & \multirow[t]{4}{*}{3} & \multirow[t]{4}{*}{.101} & \\
\hline & $2-3$ hours $(B)$ & 326 & 458.12 & & & & \\
\hline & 4-5 hours $(C)$ & 266 & 440.11 & & & & \\
\hline & $\begin{array}{l}\text { More than } 5 \text { hours } \\
\text { (D) }\end{array}$ & 264 & 489.81 & & & & \\
\hline \multirow[t]{4}{*}{ Search } & $\begin{array}{l}\text { Less than } 1 \text { hour } \\
\text { (A) }\end{array}$ & 62 & 391.69 & 11.210 & 3 & $.011 *$ & \multirow{4}{*}{$\begin{array}{l}\vartheta \\
u \\
\tilde{e} \\
\dot{\Delta}\end{array}$} \\
\hline & 2-3 hours (B) & 326 & 448.56 & & & & \\
\hline & 4-5 hours $(C)$ & 266 & 448.76 & & & & \\
\hline & $\begin{array}{l}\text { More than } 5 \text { hours } \\
\text { (D) }\end{array}$ & 264 & 499.76 & & & & \\
\hline \multirow[t]{4}{*}{ Socialization } & $\begin{array}{l}\text { Less than } 1 \text { hour } \\
\text { (A) }\end{array}$ & 62 & 377.10 & 27.485 & 3 & $.000 *$ & \multirow{4}{*}{$\begin{array}{ll}\ominus & \rho \\
\dot{v} & \vec{v} \\
\dot{v} & \tilde{\varphi}\end{array}$} \\
\hline & 2-3 hours (B) & 326 & 425.60 & & & & \\
\hline & 4-5 hours $(\mathrm{C})$ & 266 & 455.44 & & & & \\
\hline & $\begin{array}{l}\text { More than } 5 \text { hours } \\
\text { (D) }\end{array}$ & 264 & 524.80 & & & & \\
\hline News & Less than 1 hour & 62 & 434.76 & 5.176 & 3 & .159 & \\
\hline \multirow[t]{3}{*}{ follow-up } & 2-3 hours & 326 & 456.10 & & & & \\
\hline & 4-5 hours & 266 & 440.52 & & & & \\
\hline & More than 5 hours & 264 & 488.64 & & & & \\
\hline \multirow{4}{*}{$\begin{array}{l}\text { Scale } \\
\text { score }\end{array}$} & Less than 1 hour & 62 & 396.75 & 12.641 & 3 & .005 & \multirow{4}{*}{ î } \\
\hline & 2-3 hours & 326 & 447.88 & & & & \\
\hline & 4-5 hours & 266 & 443.73 & & & & \\
\hline & More than 5 hours & 264 & 504.48 & & & & \\
\hline
\end{tabular}

Table 10.

Kruskal-Wallis Test Results According to The Daily Connection Time to The Internet with MP

When Table 10 is examined, it is observed that the daily connection time with MP to the internet creates significant differences in the "Search" and "Socialization" subscales and the total score of the scale. According to the analysis conducted, the significant differences observed in the "Search" subscale and the total score of the scale are in favor of teacher candidates with more than five hours of daily connection to the internet with MP $(p<.05)$. Similar results were obtained in the "Socialization" subscale, and it was determined that the significant differences observed between the scores were in favor of students who were connected to the internet with MP for 4-5 hours and longer during the day $(\mathrm{p}<.05)$. Table 11 demonstrates the Kruskal-Wallis test results of the participants' SCA scores according to their perception of their internet usage skills on MP.

\begin{tabular}{llllllll}
\hline & Group & $\mathrm{N}$ & $\begin{array}{l}\text { Mean } \\
\text { Rank }\end{array}$ & $\chi^{2}$ & $\mathrm{Sd}$ & $\mathrm{p}$ & $\begin{array}{l}\text { Significant } \\
\text { difference }\end{array}$ \\
\hline Personal & Medium & 425 & 422.18 & 16.496 & 2 & $.000^{*}$ & $\mathrm{M}<\mathrm{A}, \mathrm{E}$ \\
business & Advanced & 368 & 484.86 & & & & \\
& Expert & 125 & 511.04 & & & & \\
\hline
\end{tabular}




\begin{tabular}{|c|c|c|c|c|c|c|c|}
\hline Search & $\begin{array}{l}\text { Medium } \\
\text { Advanced } \\
\text { Expert }\end{array}$ & $\begin{array}{l}425 \\
368 \\
125 \\
\end{array}$ & $\begin{array}{l}432.95 \\
467.97 \\
524.83\end{array}$ & 12.311 & 2 & $.002 *$ & $\mathrm{M}, \mathrm{A}<\mathrm{E}$ \\
\hline Socialization & $\begin{array}{l}\text { Medium } \\
\text { Advanced } \\
\text { Expert }\end{array}$ & $\begin{array}{l}425 \\
368 \\
125 \\
\end{array}$ & $\begin{array}{l}400.38 \\
487.32 \\
578.60 \\
\end{array}$ & 50.577 & 2 & $.000 *$ & $\begin{aligned} \mathrm{M} & <\mathrm{A}, \mathrm{E} \\
\mathrm{A} & <\mathrm{E}\end{aligned}$ \\
\hline $\begin{array}{l}\text { News follow- } \\
\text { up }\end{array}$ & $\begin{array}{l}\text { Medium } \\
\text { Advanced } \\
\text { Expert }\end{array}$ & $\begin{array}{l}425 \\
368 \\
125 \\
\end{array}$ & $\begin{array}{l}425.03 \\
480.43 \\
515.10 \\
\end{array}$ & 15.063 & 2 & $.001 *$ & $\mathrm{M}, \mathrm{A}<\mathrm{E}$ \\
\hline $\begin{array}{l}\text { Scale total } \\
\text { score }\end{array}$ & $\begin{array}{l}\text { Medium } \\
\text { Advanced } \\
\text { Expert }\end{array}$ & $\begin{array}{l}425 \\
368 \\
125\end{array}$ & $\begin{array}{l}411.68 \\
484.59 \\
548.20\end{array}$ & 31.117 & 2 & $.000 *$ & $\begin{aligned} \mathrm{M} & <\mathrm{A}, \mathrm{E} \\
\mathrm{A} & <\mathrm{E}\end{aligned}$ \\
\hline
\end{tabular}

Table 11.

Kruskal-Wallis Test Results According to Internet Usage Skills on MP

As seen in Table 11, significant differences were observed in all sub-scales among the participants based on their internet usage skills. The participants who perceive themselves as advanced level and users who perceived themselves as expert level skilled users tend to perform more cyberloafing behavior during lectures $(\mathrm{p}<.05)$. The Kruskal-Wallis test results of the teacher candidates' SCA score according to the frequency of using the internet during the lesson are given in Table 12.

\begin{tabular}{|c|c|c|c|c|c|c|c|}
\hline & Group & $\mathrm{N}$ & $\begin{array}{l}\text { Mean } \\
\text { Rank }\end{array}$ & $\chi^{2}$ & $\mathrm{Sd}$ & $\mathrm{p}$ & $\begin{array}{l}\text { Significant } \\
\text { difference }\end{array}$ \\
\hline \multirow{4}{*}{$\begin{array}{l}\text { Personal } \\
\text { business }\end{array}$} & 1-2 times $(\mathrm{A})$ & 542 & 360.60 & 31.313 & 3 & $.000 *$ & $\mathrm{~A}<\mathrm{B}, \mathrm{C}, \mathrm{D}$ \\
\hline & 3-4 times (B) & 134 & 446.55 & & & & \\
\hline & 5-6 times $(\mathrm{C})$ & 32 & 460.97 & & & & \\
\hline & At each opportunity (D) & 71 & 475.74 & & & & \\
\hline \multirow[t]{4}{*}{ Search } & $1-2$ times $(\mathrm{A})$ & 542 & 355.29 & 56.376 & 3 & $.000^{*}$ & $\mathrm{~A}<\mathrm{B}, \mathrm{C}, \mathrm{D}$ \\
\hline & 3-4 times (B) & 134 & 428.65 & & & & $\mathrm{~B}, \mathrm{C}<\mathrm{D}$ \\
\hline & 5-6 times $(\mathrm{C})$ & 32 & 460.28 & & & & \\
\hline & At each opportunity (D) & 71 & 550.36 & & & & \\
\hline \multirow[t]{4}{*}{ Socialization } & 1-2 times $(\mathrm{A})$ & 542 & 359.65 & 35.166 & 3 & $.000 *$ & $\mathrm{~A}<\mathrm{B}, \mathrm{C}, \mathrm{D}$ \\
\hline & 3-4 times (B) & 134 & 438.74 & & & & \\
\hline & 5-6 times $(\mathrm{C})$ & 32 & 487.58 & & & & \\
\hline & At each opportunity (D) & 71 & 485.75 & & & & \\
\hline \multirow{4}{*}{$\begin{array}{l}\text { News } \\
\text { follow-up }\end{array}$} & $1-2$ times $(\mathrm{A})$ & 542 & 369.20 & 23.309 & 3 & $.000^{*}$ & $\mathrm{~A}, \mathrm{~B}<\mathrm{D}$ \\
\hline & 3-4 times (B) & 134 & 407.30 & & & & \\
\hline & 5-6 times $(\mathrm{C})$ & 32 & 425.92 & & & & \\
\hline & At each opportunity (D) & 71 & 499.92 & & & & \\
\hline \multirow{4}{*}{$\begin{array}{l}\text { Scale } \\
\text { score }\end{array}$} & $1-2$ times $(\mathrm{A})$ & 542 & 355.44 & 47.599 & 3 & $.000^{*}$ & $\mathrm{~A}<\mathrm{B}, \mathrm{C}, \mathrm{D}$ \\
\hline & 3-4 times $(\mathrm{B})$ & 134 & 441.72 & & & & $\mathrm{~B}<\mathrm{D}$ \\
\hline & 5-6 times $(\mathrm{C})$ & 32 & 471.27 & & & & \\
\hline & At each opportunity (D) & 71 & 519.58 & & & & \\
\hline
\end{tabular}

Table 12.

Kruskal-Wallis Test Results according to the Frequency of Using the Internet on MP in The Educational Setting

As Table 12 represents, the frequency of using the internet on MP in the educational setting creates significant differences in the SCA scores of teacher candidates $(p<.05)$. According to the 
analysis, the cyberloafing behavior levels of the students who used the internet on MP 1-2 times during the lesson were significantly lower compared to the teacher candidates using the internet more frequently in the all subscales $(\mathrm{p}<.05)$. The Kruskal-Wallis test results of the SCA scores of the participants according to how much time without interruption they spend on the internet using MP in the educational setting are shown in Table 13.

\begin{tabular}{|c|c|c|c|c|c|c|c|}
\hline & Group & $\mathrm{N}$ & $\begin{array}{l}\text { Mean } \\
\text { Rank }\end{array}$ & $\chi^{2}$ & Sd & $\mathrm{p}$ & $\begin{array}{l}\text { Significant } \\
\text { difference }\end{array}$ \\
\hline \multirow[t]{5}{*}{$\begin{array}{l}\text { Personal } \\
\text { business }\end{array}$} & $\begin{array}{l}\text { Less than } 1 \\
\min (\mathrm{A})\end{array}$ & 359 & 389.68 & 46.774 & 4 & \multirow[t]{5}{*}{$.000 *$} & $\mathrm{~A}<\mathrm{B}, \mathrm{C}, \mathrm{D}, \mathrm{E}$ \\
\hline & $2-3 \min (B)$ & 299 & 484.87 & & & & $\mathrm{~B}<\mathrm{E}$ \\
\hline & $3-4 \min (C)$ & 136 & 511.71 & & & & \\
\hline & $5-6 \min (\mathrm{D})$ & 55 & 512.91 & & & & \\
\hline & $6 \min +(E)$ & 69 & 567.35 & & & & \\
\hline \multirow[t]{5}{*}{ Search } & $\begin{array}{l}\text { Less than } 1 \\
\min (\mathrm{A})\end{array}$ & 359 & 401.40 & 47.296 & 4 & \multirow[t]{5}{*}{$.000^{*}$} & $\mathrm{~A}<\mathrm{B}, \mathrm{C}, \mathrm{D}, \mathrm{E}$ \\
\hline & $2-3 \min (B)$ & 299 & 463.07 & & & & $\mathrm{~B}, \mathrm{C}, \mathrm{D}<\mathrm{E}$ \\
\hline & $3-4 \min (C)$ & 136 & 503.89 & & & & \\
\hline & $5-6 \min (\mathrm{D})$ & 55 & 516.05 & & & & \\
\hline & $6 \min +(\mathrm{E})$ & 69 & 613.78 & & & & \\
\hline \multirow[t]{5}{*}{ Socialization } & $\begin{array}{l}\text { Less than } 1 \\
\min (\mathrm{A})\end{array}$ & 359 & 399.39 & 43.503 & 4 & \multirow[t]{5}{*}{$.000^{*}$} & $\mathrm{~A}<\mathrm{B}, \mathrm{C}, \mathrm{D}, \mathrm{E}$ \\
\hline & $2-3 \min (B)$ & 299 & 480.52 & & & & $\mathrm{~B}, \mathrm{C}<\mathrm{E}$ \\
\hline & $3-4 \min (C)$ & 136 & 476.19 & & & & \\
\hline & $5-6 \min (\mathrm{D})$ & 55 & 518.22 & & & & \\
\hline & $6 \min +(E)$ & 69 & 601.49 & & & & \\
\hline \multirow[t]{5}{*}{$\begin{array}{l}\text { News } \\
\text { follow-up }\end{array}$} & $\begin{array}{l}\text { Less than } 1 \\
\min (\mathrm{A})\end{array}$ & 359 & 391.13 & 54.234 & 4 & \multirow[t]{5}{*}{$.000 *$} & $\mathrm{~A}<\mathrm{B}, \mathrm{C}, \mathrm{D}, \mathrm{E}$ \\
\hline & $2-3 \min (B)$ & 299 & 478.64 & & & & $\mathrm{~B}, \mathrm{C}, \mathrm{D}<\mathrm{E}$ \\
\hline & $3-4 \min (C)$ & 136 & 494.94 & & & & \\
\hline & $5-6 \min (\mathrm{D})$ & 55 & 522.02 & & & & \\
\hline & $6 \min +(E)$ & 69 & 612.57 & & & & \\
\hline \multirow[t]{5}{*}{$\begin{array}{l}\text { Scale total } \\
\text { score }\end{array}$} & $\begin{array}{l}\text { Less than } 1 \\
\min (\mathrm{A})\end{array}$ & 359 & 386.13 & 61.038 & 4 & \multirow[t]{5}{*}{$.000 *$} & $\mathrm{~A}<\mathrm{B}, \mathrm{C}, \mathrm{D}, \mathrm{E}$ \\
\hline & $2-3 \min (B)$ & 299 & 478.27 & & & & $\mathrm{~B}, \mathrm{C}, \mathrm{D}<\mathrm{E}$ \\
\hline & $3-4 \min (C)$ & 136 & 505.74 & & & & \\
\hline & $5-6 \min (\mathrm{D})$ & 55 & 522.77 & & & & \\
\hline & $6 \min +(E)$ & 69 & 618.33 & & & & \\
\hline
\end{tabular}

Table 13.

Kruskal-Wallis Test Results according to the Time Spent on the Internet on MP in the Educational Setting

As seen in Table 13, as the time that teacher candidates spend on the internet using MP in the educational setting increases, their cyberloafing levels also increase in all subscales and the overall scale $(\mathrm{p}<.05)$.

\section{Discussion:}

As a result of this study, it was determined that $48.4 \%$ of the teacher candidates had been using the internet service on their mobile phones for 5-9 years, 35.5\% accessed the internet for 23 hours during the day, and $28.8 \%$ used the internet on MP for more than five hours a day. Of the participants, $46.3 \%$ expressed their internet usage skill on MP as "medium," and $40.1 \%$ as 
"advanced." These results were similar to the results of the research by Çakmak and Yalçın (2013), which detected that the mobile phone usage experience of university students was an average of seven and a half years, and by Doğan, Kalkan and Aydın (2017), which determined that $80 \%$ of the participants used the internet for 5-6 years. Furthermore, many studies show that university students spend an average of 1-5 hours a day on the internet (Alan, 2019; Yazgan \& Y1ldirım, 2020; Salıc1 \& Öcal, 2020) and define their internet usage skills on mobile phone as medium and advanced (Çok \& Kutlu, 2018). Therefore, it can be said that nowadays, when information and communication technologies are developing rapidly, technological devices and the internet have become an important part of daily lives, and the usage of mobile phones and the internet in daily life is spreading rapidly.

The findings demonstrate that $77.2 \%$ of the teacher candidates do not approve of using the internet on MP instead of dealing with the lesson in the educational setting; however, more than $90 \%$ of the participants used the internet at least 1-2 times during the lesson. Similar results were found in the research studies done by Arabac1, 2017; Tindell and Bohlander, 2012. In addition to communication services, modern mobile devices also provide opportunities such as accessing social networks, e.g. Facebook or Twitter, playing online and offline games, and surfing the internet. The constant updating of both mobile phones and social media, being open to multiple usage, and allowing virtual sharing have made them one of the most effective tools in terms of interpersonal communication. Therefore, mobile phones and social media have become an indispensable part of life for individuals of almost every age in almost every field and environment, from the social environment to the business environment, from politics to education (Akgün, 2020; Altay\& Özerbaş, 2020; Büyükbayraktar, 2020).

According to the results obtained from the overall scale, teacher candidates rarely do cyberloafing during the lesson. It is an expected behavior for the participants, who will take a significant place in shaping the future, to be sensitive about cyberloafing, which is generally accepted as an undesirable behavior. The reviewed studies indicate that the cyberloafing level of university students was medium and above medium (Çok \& Kutlu, 2018; Seçkin \& Kerse, 2017; Şenel et al., 2019). These differences in the results might originate from the fact that the studies were conducted with students from different universities, faculties, and departments. It can be said that this result is due to direct interaction with computers, considering that most studies on cyberloafing behavior in the educational setting are carried out with students from programs in which computer technologies are used extensively.

The findings demonstrate that teacher candidates' cyberloafing behavior mostly occur in the form of socializing (visiting virtual communities and social networks such as Facebook or Twitter) and following news (visiting news sites and newsgroups). Relatively more frequent behavior in the "Personal business" subscale includes downloading files and reading blog pages, while in the "Search" subscale, searching for interesting topics and searching for interesting sites (pictures, videos, quotations) not related to the lesson are included. Many studies indicate that university students mostly do cyberloafing within the areas of messaging, visiting social networking sites and news sites (Arabac1, 2017; Cha \& Seo, 2018; Çok \& Kutlu, 2018; Seçkin \& Kerse, 2017; Şenel et al. 2019; Twum, Yarkwah, \& Nkrumah, 2021; Y1ldırım, 2016). In the study conducted by Özdem and Demir (2015), the most frequent cyberloafing behavior of school administrators was to participate in social networks like Facebook and Twitter. In the study carried out by Bağrıaçık Yılmaz (2017) with graduate students, the majority of whom were teachers, the most frequent cyberloafing behavior was visiting Facebook. In the study performed by Örücü and Y1ld1z (2014) among academicians, it was observed that the behavior of visiting news websites (newspapers, online news TV, and other news websites) on the internet was at a high level. Therefore, the reason for the fact that the most frequently observed cyberloafing activities in the 
studies are messaging and visiting social networking sites may be the desire of people to check their social media accounts and to follow what is happening by staying online. This view is supported by a significantly higher cyberloafing level of students with a greater number of social media accounts who are more frequently checking their social media accounts during the lesson compared to other students (Ar1kan \& Özgür, 2019; Gezgin, et al. 2018). The fact that students regarded short-term internet access as an unimportant/ordinary behavior that could not adversely affect learning or the classroom environment may have led to this result. As stated by Şenel et al. (2019), students see the internet as a savior when they are bored during the lesson to distract them or when they are curious about something. Considering that mobile phones are nowadays always with students, notification sounds/or signals coming from mobile phone may be unconsciously directing students to cyberloafing.

As a result of this study, it was observed that the cyberloafing level of male participants was significantly higher than that of female teacher candidates. This can be interpreted as male students' reflecting their fondness for technology and the internet (Salıc1 \& Öcal, 2020) in the classroom environment. However, there are no definite results indicating whether cyberloafing differs by gender or not. In related literature, there are studies reaching results similar to this study (Arıkan \& Özgür, 2019; Çok \& Kutlu, 2018; Hayıt \& Dönmez, 2016) while other studies indicate that women's cyberloafing levels are higher (Knight, 2017) or that cyberloafing does not depend on gender (Bağrıaçık Yılmaz, 2018; Doğusoy et al., 2020; Tanrıverdi \& Karaca, 2018).

Another important result obtained from the study is that the cyberloafing level of teacher candidates who are aged 18-20 and in their first year are lower than those in other age groups and grade levels. Students in this age group (18-20 years) are at the beginning of their university education. Their high motivation, being more interested in the lessons, and possibly being more careful about obeying the classroom rules, or their hesitation to do cyberloafing in the classroom may have caused this result. In related literature, there are further studies showing that university students in the 21-23 age group are more dependent on their mobile phones (Kuyucu, 2017) and that excessive use and virtual-oriented relationships are more common among people aged 21-25 (Minaz \& Çetinkaya Bozkurt, 2017). In their study performed on university students, Seçkin and Kerse (2017) concluded that lower-grade students do less cyberloafing than upper-grade students. Similar results were obtained in studies carried out by Arabac1 (2017) and Yaşar (2013), and it was determined that 4 th-grade students engage more in cyberloafing than students at other grade levels. This result may be caused by the fact that students toward the end of their studies think that they have basic knowledge about their profession or that their interests change and diversify with increasing age. However, there are also studies indicating that grade levels do not have a significant effect on cyberloafing behavior (Keser et al., 2016; Gezgin et al., 2018).

While there were no statistically significant difference in the participants' cyberloafing behavior levels according to the duration of using internet service on their mobile phones, the level of cyberloafing was higher for teacher candidates whose daily connection time to the internet from their mobile phones was more than five hours. As a result of their study, Kumar and Mondal (2018) observed that individuals with internet addiction stayed online for 3-4 hours per day. Sağar and Kök Eren (2018) stated that $46.7 \%$ of university students used the internet for 4-6 hours, $18.4 \%$ for 7-9 hours, and $16.9 \%$ used it for 10 hours and more. Approximately 37\% of the participants used the internet for 5 hours and more a day. Another finding obtained in the research is that the participants who defined their internet usage skill on mobile phones as "advanced" or "expertise" had higher levels of cyberloafing in the "Personal business" and "Socialization" subscales as well as the overall scale. In other words, students with higher skill levels can easily perform their daily personal business activities (banking transactions, online shopping, etc.), e-mail control, and filesharing on their mobile phones when they have access to the internet. According to the studies 
carried out by Yaşar (2013) and Kalaycı (2010) with university students, students with "expert" internet usage skills exhibit more "Personal business" and "News follow-up" cyberloafing behavior than students with "medium" skills. In this case, it can be concluded that internet access as well as students' internet usage habits and skills trigger cyberloafing. The fact that as the frequency of using the internet during the lesson and the duration of staying on the internet increase, the cyberloafing behavior level of teacher candidates also increase, according to the findings of this study, supports this view and shows that the research findings are consistent. According to the study performed by Gökdaş et al. (2014) with teacher candidates, $80.1 \%$ of the participants use mobile phones during the lesson and $46.5 \%$ of them frequently check their messages. In line with these results, it is expected that even having a smartphone is sufficient to increase cyberloafing (Seçkin \& Kerse, 2017), that students who have more features/applications on their mobile phones spend more time on the internet and that students with higher internet skills do more cyberloafing.

This study revealed that students at the Science Education, Social Sciences Education, and Turkish Education Departments did relatively more cyberloafing during the lesson than teacher candidates from other departments. While there is no significant difference in most related literature regarding the cyberloafing scores of teacher candidates according to their departments and their department satisfaction levels (Arıkan \& Özgür, 2019; Doğusoy et al., 2020; Polat, 2018), the study carried out by Çok \& Kutlu (2018) concluded that the cyberloafing behaviors of university students varied significantly according to their level of satisfaction with the department. This result may be due to differences in career plans, educational objectives, and academic satisfaction with their education of the students in the study sample and the structural characteristics of the curricula of the departments where the study was conducted.

\section{Conclusion:}

As a result, this study revealed that more than half of the teacher candidates used their mobile phones at least 1-2 times during the lesson and stayed on the internet for 2-3 minutes, that more than half of the participants defined their internet usage skills as advanced or expert, and as their expertise increased, the level of cyberloafing also increased. Furthermore, it was determined that the more experienced teacher candidates in the third and fourth year have a higher frequency of using the internet on the mobile phone during the lesson and the level of cyberloafing increased compared to younger students. Accordingly, it may be recommended that instructors try to reduce teacher candidates' desire to engage in cyberloafing by planning activities that will activate their internet usage skills within the teaching process (such as doing research on the internet, gamebased learning, encouraging them to search on the internet by asking curious questions). The correct use of the internet in the educational setting may be effective in controlling cyberloafing behavior and increasing the efficiency of the lesson. To reduce the frequency of mobile phone usage during the lesson, it may be suggested to review the rules and procedures regarding mobile phone usage and to reorganize them in line with the activities. Especially in the third and fourth grades, it may be suggested to focus on teaching practices rather than theoretical knowledge, and activities such as discussions, brainstorming, and evaluation of school practices to involve students actively in the process and share their thoughts and experiences.

The results of this study should be evaluated to the extent of its limitations. This study was conducted with students attending different departments of the education faculty at a state university. To achieve generalizations on this subject, comparative studies could be carried out with students attending different faculties and departments of the same university. The condition regarding the Turkish sample can be revealed by collecting data from state and private universities. The data in this study were collected from teacher candidates by applying a survey/scale to them. 
The opinions of instructors with regard to students' cyberloafing level in the educational setting could also be examined. 


\section{References:}

Ahmad, A. \& Omar, Z (2017). Understanding who cyberloafs from the self-control perspective: A study in the public service sector. International Journal of Advanced and Applied Sciences, 4(8), 123-128.

Akbulut, Y., Dursun, Ö. Ö., Dönmez, O. \& Şahin, Y. L. (2016). In search of a measure to investigate cyberloafing in educational settings. Computers in Human Behavior, 55, 616-625.

Akgün, F. (2020). Investigation of high school students' cyberloafing behaviors in classes. Education and Science, 45 (201), 79-108.

Alan, H. (2019). Sosyal ağ kullanımı yoğunluğu ve sanal kaytarma davranışları: Üniversite öğrencileri üzerine bir inceleme. Çağdaş Yönetim Bilimleri Dergisi, 6(2), 112-129.

Alanoglu, M. \& Karabatak, S. (2021). Examining of the smartphone cyberloafing in the class: Relationship with the attitude towards learning and prevention of cyberloafing. International Journal of Technology in Education (IJTE), 4(3), 351-372.

Altay, D. \& Özerbaş, M. (2020). İlkokul öğrencilerinin problemli cep telefonu kullanımlarının farklı değişkenler açısından incelenmesi. TÜBAV Bilim Dergisi, 13 (1), 68-84.

Andreassen, C. S., Torheseim, T., \& Pallesen, S. (2014). Predictors of use of social network sites at work- a specific type of cyberloafing. Journal of Computer-Mediated Communication, 19 (2014), 906-921

Arabac1, İ. B. (2017). Investigation faculty of education students' cyberloafing behaviors in terms of various variables. The Turkish Online Journal of Educational Technology, 16 (1), 72-82.

Arıkan, F.\& Özgür, H. (2019). Investigation of cyberloafing and cognitive absorption levels of prospective teachers in terms of various variables. Trakya Üniversitesi Sosyal Bilimler Dergisi, 21 (2), 863-885.

Bağrıçık Yılmaz, A. (2017). Investigation of cyberloafing levels of graduate students in terms of various variables: a mixed method study. KEFAD, 18(2), 113-134.

Baert, S., Vujić, S., Amez, S., Claeskens, M., Daman, T., Maeckelberghe, A., \& De Marez, L. (2020). Smartphone use and academic performance: Correlation or causal relationship. Kyklos, 73(1), 22-46.

Blanchard, A. \& Henle, C. (2008). Correlates of different forms of cyberloafing: The role of norms and external locus of control. Computers in Human Behavior, 24(3), 1067-1084.

Bock, G.W. \& Ho. S.L. (2009). Non-work related computing (NWRC). Communications of The Acm, 52, 124-128.

Büyüköztürk, Ş. (2020). Sosyal bilimler için veri analizi el kitabı (28. Bask1). Ankara: Pegem A Yayınc1lik.

Büyükbayraktar, Ç. G. (2020). Predictive relationships among smartphone addiction, fear of missing out and interaction anxiousness. European Journal of Educational Sciences, 7 (2), 1-16. Candan, H., \& İnce, M. (2016). A research on the relationship between cyberloafing and organizational commitment of police department personnel. Niğde Üniversitesi İktisadi ve İdari Bilimler Fakültesi Dergisi, 9(1), 229-235.

Cha, S. S., \& Seo, B. K. (2018). Smartphone use and smartphone addiction in middle school students in Korea: Prevalence, social networking service, and game use. Health Psychology Open, January-June, 1-15.

Çakmak, T., \& Yalçın, H. (2013). The use of mobile technology by university students: The sample of the Department of Information Management at Hacettepe University. Hacettepe Üniversitesi Türkiyat Araştırmaları Dergisi, 2013 Bahar 18, 47-61

Çınar, O. \& Cinisli, Z. (2018). In-class cyberloafing among undergraduate students of physical education and sports teaching department. BESAD, 10(1), 39-48.

Çok, R., \& Kutlu, M. (2018). An examination of the relationship between non-course related internet usage during course time and academic motivation level of university students in terms of various variables. The Journal of International Lingual, Social and Educational Sciences, 4 (1), 121. 
Demir, M., Tan, M. (2018). İş görenlerin demografik özellikleri ve sanal kaytarma davranış1 arasındaki ilişki. Journal of Tourism Theory and Research, 4(1), 40-56. DOI: 10.24288/jttr.375791 Doğan, A., Kalkan, N. \& Aydın, C. C. (2017). Önlisans ve lisans öğrencilerinin internet kullanım seviyelerinin karşılaştırılması ve eğitime katkısı; Hacettepe Üniversitesi örneği. YILDIZ Journal of Educational Research, 2(2), 1-20.

Doğusoy, B., Sevinç, M. \& Ergün, H. (2020). Investigation of cyberloafing behavior of prospective teachers according to different variables. Kastamonu Education Journal, 28 (3), 1321-1332. doi: 10.24106/kefdergi.3898.

Gezgin, D.M., Kamalı Arslantaş, T., \& Şumuer, E. (2018). An investigation of the cyberloafing levels of vocational and technical high school students according to different variables. Ege Eğitim Dergisi, 19(2), 408-424. Gökdaş, İ., Torun, F., \& Bağrıaçık, A. (2014). Teacher candidates' mobile phones educational use situations and opinions on mobile learning. Adnan Menderes Üniversitesi Eğitim Fakültesi Eğitim Bilimleri Dergisi, 5(2), 43-61.

Hayıt, T., \& Dönmez, O. (2016). Investigation of the relationship between cyber-loafing profilesand cognitive absorption of university students. Eğitim ve Öğretim Araştırmaları Dergisi, 5, (16), 2146-9199.

Heflin, H., Shewmaker, J., \& Nguyen, J. (2017). Impact of mobile technology on student attitudes, engagement, and learning. Computers and Education, 107, 91-99.

Holguin, E. S. (2016). Strategies functional managers use to control cyberloafing behaviors. Unpublished doctorate dissertation. Walden University, USA.

Huma, Z., Hussain, S., Thurasamy, R., \& Malik, M.I. (2017). Determinants of cyberloafing: A comparative study of a public and private sector organization. Internet Research, 27 (1), 97-117. Jiang, F., Lin, S. \& Mariano, J. M. (2016). The influence of Chinese college teachers' competence for purpose support on students' purpose development. Journal of Education for Teaching, 42(5), 565-581.

Kalayc1, E. (2010). The investigation of relationship between cyberloafing and self-regulated learning strategies among undergraduate students. Unpublished master's thesis. Hacettepe Üniversitesi, Ankara.

Keser, H., Kavuk, M., \& Numanoglu, G. (2016). The relationship between Cyber-Loafing and internet addiction. Cypriot Journal of Educational Science, 11(1), 37-42.

Knight, R. (2017). Academic cyberloafing: a study of perceptual and behavioral differences on inclass cyberloafing among undergraduate students. Unpublished master's thesis. East Carolina University, USA.

Koay, K. Y., Soh, P.C.H., \& Chew, K.W. (2017). Antecedents and consequences of cyberloafing: Evidence from the Malaysian ICT industry. First Monday, 22 (3-6), 1-16.

Kumar, M., \& Mondal, A. (2018). A study on Internet addiction and its relation to psychopathology and self-esteem among college students. Industrial Psychiatry Journal, 27 (1), 61-66.

Kuyucu, M. (2017). Gençlerde akıllı telefon kullanımı ve akıllı telefon bağımlılığı sorunsalı: "Akıllı telefon(kolik)" üniversite gençliği. Global Media Journal TR Edition, 7(14), 320-351.

Lepp, A., Barkley, J. E., Aryn, C. K. (2015). The relationship between cell phone use and academic performance in a sample of U.S. college students. Retrieved July 20, 2019, from https://journals.sagepub.com

Lim, V.K.G. (2002). The it way of loafing on the job: Cyberloafing, neutralizing and organizational justice. Journal of Organizational Behavior, 23, 675-694.

Minaz, A., \& Çetinkaya Bozkurt, Ö. (2017). Investigation of university student's smartphone addiction levels and usage purposes in terms of different variables. Mehmet Akif Ersoy Üniversitesi Sosyal Bilimler Dergisi, 9(21), 268-286.

Örücü, E., \& Yıldız, H. (2014). İşyerinde kişisel internet ve teknoloji kullanımı: Sanal kaytarma. Ege Akademik Bakış, 14(1), 99.

Özdem, G., \& Demir, A. (2015). Cyber loafing behavior of school administrators. Mersin Üniversitesi Eğitim Fakültesi Dergisi, 11(3), 1029-1042. 
Rayan, A., Dadoul, A. M., Jabareen, H., Sulieman, Z., Alzayyat, A., \& Baker, O. (2016). Internet use among university students in south west bank: Prevalence, advantages and disadvantages, and association with psychological health. International Journal of Mental Health and Addiction, 15(1), 118-129.

Sağar, M.E., \& Kök Eren, H. (2018). Bir grup üniversite öğrencisinin internet bağımlılıklarının incelenmesi. Akademik Sosyal Araştırmalar Dergisi, 6 (80), 523-534

Salıc1, O., \& Öcal, Z.S.S. (2020). University students' internet addiction levels under various variables. European Journal of Educational Sciences, 7 (3), 109-122.

Sarhangpour, H., Baezzat F., \& Akbari, A. (2018). Predicting cyberloafing through psychological needs with conscientiousness and being goal-oriented as mediators among university students. International Journal of Psychology, 12 (2), 147-168.

Seçkin, Z. \& Kerse, G. (2017). Cyberloafing behaviors of university students and an examination of such behaviors in view ofassortedvariables: An empirical research. Aksaray Üniversitesi İktisadi ve İdari Bilimler Fakültesi Dergisi, 9 (1), 89-110.

Soh, P. C-H, Koay, K. Y., \& Lim, V. K. G. (2018). Understanding cyberloafing by students through the lens of an extended theory of planned behavior. First Monday, 23 (6-4), 1-18.

Şenel, S., Günaydın, S., Sarıtaş, M.T., \& Çiğdem, H. (2019). The factors predicting cyberloafing behaviors of undergraduate students. Kastamonu Eğitim Dergisi, 27(1), 95-105.

Tanrıverdi, Ö. \& Karaca, F. (2018). Investigating the relationships between adolescents' levels of cognitive absorption and cyberloafing activities according to demographic characteristics. Addicta: The Turkish Journal on Addictions, 5(2), 285-315.

Tindell, D. R., \& Bohlander, R.W. (2012). The use and abuse of cell phones sand text messaging in the classroom: A survey of college students. College Teaching, 60 (1), 1-9.

TURKSTAT (2018). Türkiye İstatistik Kurumu, Türkiye'nin internet kullanma alışkanlıkları. Retrieved 22.02.2019 from https://www.guvenliweb.org.tr/haber-detay/turkiyenin-internetkullanim-aliskanliklari-tuik-2018

Twum, R., Yarkwah, C., \& Nkrumah, I. K. (2021). Utilisation of the internet for cyberloafing activities among university students. Journal of Digital Educational Technology, 1(1), ep2101. https://doi.org/10.21601/jdet/10912

Ugrin, J. C., Pearson, J. M. \& Odom, M. D. (2008). Profiling cyber-slackers in the workplace: Demographic, cultural, and workplace factors. Journal of Internet Commerce, 6(3), 75 -89.

Varol, F. \& Yildirım, E. (2018). An examination of cyberloafing behaviors in classrooms from students' perspectives. Turkish Online Journal of Qualitative Inquiry, 9(1), 26-46.

Wu, J., Mei, W., \& Ugrin, J. C. (2018). Student cyberloafing in and out of the classroom in China and the relationship with student performance. Cyberpsychology, Behavior, and Social Networking, 21 (3), 199-204.

Yaşar, S. (2013). The effects of students' locus of control and attitudes towards computer laboratory on their cyberloafing behaviour. Unpublished master's thesis. Hacettepe Üniversitesi, Ankara.

Yazgan, Ç.Ü., \& Yıldırım, A. F. (2020). Üniversite gençliğinde internet bağımlılığı ve derslerde siber aylaklık davranışları. Gençlik Araştırmaları Dergisi, 8 (Özel Sayı), 5-23.

Y1ldırım, E. (2016). Case study for elementary school teacher candidates' cyberloafing behaviors. Unpublished master's thesis. Firat Üniversitesi, Elazığ. 